\title{
MAATSKAPLIKE WERK GROEPSINTERVENSIE VIR SLAGOFFERS VAN BOELIEGEDRAG: FUNKSIONELE ELEMENTE
}

\author{
Author: \\ A Nepgen ${ }^{1}$ \\ $M$ van der Merwe $^{2}$

\section{Affiliation:} \\ ${ }^{1}$ At the time research, \\ Compres, Sentrum \\ vir Kinder-, Jeug en \\ Familiestudies, Fakulteit \\ Gesondheidswetenskappe, \\ NWU \\ ${ }^{2}$ Compres, Sentrum \\ vir Kinder-, Jeug en \\ Familiestudies, Fakulteit \\ Gesondheidswetenskappe, \\ NWU
}

\section{Correspondence to:}

A Nepgen

Email:

andrivs@gmail.com

Postal Address:

Sentrum vir Kinder-, Jeug en Familiestudies, Hoek van Oos en Malherbestraat, Wellington, 7655

\section{Correspondence to:}

$M$ van der Merwe

Email:

23376244@nwu.ac.za

\section{Postal Address:}

Sentrum vir Kinder-, Jeug en Familiestudies, Hoek van Oos en Malherbestraat, Wellington, 7655

Dates:

15 August 2016

\section{How to cite this article:} Nepgen, A \& van der Merwe, M, 2016. "MAATSKAPLIKE WERK GROEPSINTERVENSIE VIR SLAGOFFERS VAN BOELIEGEDRAG: FUNKSIONELE ELEMENTE". KOERS - Bulletin for Christian Scholarship, 81(1). Available at: http://dx.doi. org/10.19108/KOERS.81.1.2260

\section{Copyright:}

(C) 2015. The Author(s). Published under the Creative Commons Atribution License.
This article covers part of a research project aimed at the development of an intervention for use in group work with children in their late middle childhood who are victims of bullying behaviour. In the second phase of the intervention research, namely the collection and synthesis of data, the opinions of professional persons were sought in a focus group regarding the essence of the problem as well as to identify functional elements that needed to be included in the intervention. In order to refine the intervention prototype, it was important for the voices of the victims of bullying participants to be heard about their experience and management of bullying behaviour, and to discuss alternative ways of managing bullying. The opinions of the parents of victims of bullying participants, regarding their children's inclusion in the intervention prototype, are also included as part of the early development and pre-test phase data. Data collection is supplemented by comprehensive literature research. Four themes were identified and are discussed in this article.

Key terms: Bullying behaviour, Bio-ecological perspective, Circle of Hope model, fundamental human needs.

Hierdie artikel bied 'n oorsig oor 'n gedeelte van 'n navorsingstudie wat daarop gerig was om 'n intervensie in groepsverband te ontwikkel vir kinders in hullaat middelkinderjare wat slagoffers is van boeliegedrag. In die tweede fase van intervensie-navorsing, naamlik die insameling en sintese van data, is menings van professionele persone in 'n fokusgroep verkry oor die aard van die probleem en ook om funksionele elemente te identifiseer vir insluiting in die intervensie. Vir die verfyning van die intervensie-prototipe was dit belangrik om slagofferdeelnemers se stemme te hoor oor hoe hulle boeliegedrag ervaar en hanteer; en alternatiewe wyses van hantering te bespreek. Die ouers van slagofferdeelnemers se menings oor hul kinders se inskakeling by die intervensie-prototipe word ook weergegee as deel van die vroeë ontwikkeling en voortoetsfase. Data-insameling is aangevul met ' $n$ literatuurstudie. Vier temas is geïdentifiseer en word in die artikel beskryf.

Sleutelterme: Boeliegedrag, Bio-ekologiese perspektief, Sirkel van Hoop-model, fundamentele menslike behoeftes. 


\section{INLEIDING}

Boeliegedrag word beskryf as die opsetlike, aggressiewe, herhaaldelike verbale of nie-verbale optrede teenoor ander persone (wat dit moeilik vind om hulleself te beskerm) en wat sielkundige of fisieke leed kan veroorsaak (Olweus \& Limber, 2010:125). Rigby (2007:15) verwys na herhaaldelike handeling wat sielkundige en fisieke leed veroorsaak, maar beklemtoon ook die wanbalans in mag tussen boelies en slagoffers. Laasgenoemde kan meegebring word deur faktore soos fisieke voorkoms, sosiale en ekonomiese status, intellektuele vermoëns en gesinsagtergrond (Craig \& Pepler, 2007:86). Kinders kan ook individueel of as deel van groepe geboelie word deur een of meer boelies (Olweus \& Limber, 2010:124; Rigby, 2007:15; Sullivan, 2011:9-10). Olweus (2001:6) identifiseer fisieke boeliegedrag, die gebruik van verbale dreigemente en dwang as vorme van direkte boeliegedrag. Indirekte boeliegedrag kom voor wanneer persone aktief uit groepe gesluit word of onwaarhede en skinderstories versprei word, wat tegnologiese teistering insluit.

Boeliegedrag beïnvloed kinders op verskillende vlakke waaronder die emosionele vlak (Govender, 2013:68; Swearer et al., 2009:54, 64, 98; Rigby, 2007:56-57) en dit kan as traumaties deur slagoffers ervaar word (Mishna \& Sawer, 2012:164). Boeliegedrag kan ook lei tot depressie, angs en selfdood (Hansen, 2012:386; Swearer et al., 2009:98). Op die fisieke vlak lei boeliegedrag tot simptome soos hoofpyn en abdominale pyn. Dit kan gedragsmanifestasies hê soos slaapprobleme en nagmerries, bednatmaak, naels kou, regressie tot vorige ontwikkelingstadiums en afname in eetlus (Fekkes et al., 2006:1572-1573, Rigby, 2007:54-56; Swearer et al., 2009:16-17). Dieverbandtussenspanningwatervaarwordendieontwikkeling van somatiese en sielkundige gesondheidsprobleme word ook beklemtoon (Fekkes et al., 2006:1572; Greco et al., 2007: 326-327; Hjern et al., 2008:115-117). Blootstelling aan boeliegedrag kan slagoffers se selfbeeld negatief beïnvloed (Swearer et al., 2009:16-17; Rigby, 2007:50-51) en veroorsaak dat hulle onseker word van die self (Marais \& Meier, 2010:51), wat 'n vermindering aan selfvertroue meebring (Rigby, 2012:17). Dit benadeel ook sosiale verhoudings (Georgiou \& Stavrinides, 2008:583; Rigby, 2007:51-52, 584). Volgens Meier en Marais (2010:51) en Neser (2006:141) het slagoffers van boeliegedrag normaalweg min vriende en word hulle nie deur portuurgroepe aanvaar nie. Akademiese vordering kan benadeel word (Dussich \& Maekoya, 2007:495; Nel, 2016:19; Neser, 2006:138; Rigby, 2007:52-53; Swearer et al., 2009:17) omdat slagoffers dit vermy om skool by te woon. Die negatiewe effek op konsentrasie kan daartoe lei dat skoolwerk nadelig beïnvloed word (Govender, 2013:68). Die invloed van boeliegedrag op spiritualiteit en religie word deur Carter et al. (2013:156-158) uitgelig. Boeliegedrag is dus duidelik 'n komplekse verskynsel wat die interaksie tussen boelies, slagoffers en omstanders insluit.

Hierdie studie het spesifiek gefokus op kinders in hul laat middelkinderjare omdat kinders in hierdie ontwikkelingsfase begin gereedmaak vir die oorgang na hoërskool. Hul skolastiese vordering moet op standaard wees en ontwikkelingsmylpale moet bereik word ter voorbereiding van die adolessente lewensfase wat volg. Blootstelling aan boeliegedrag kan meebring dat kinders skolasties onderpresteer en ontwikkelingsmylpale nie bereik word nie. Indien die effek van blootstelling aan negatiewe situasies soos boeliegedrag nie reeds in die laat middelkinderjare aangespreek word nie, kan dit kinders se totale funksionering beïnvloed. Verder was dit noodsaaklik dat die intervensie gefokus moet wees. Die breë kategorie van die middelkinderjare is té wyd omdat ontwikkeling in hierdie fase so vinnig plaasvind en daar groot verskille bestaan in die funksionering van kinders in die vroeë laerskooljare teenoor funksionering in Graad 5 tot 7.

\section{NAVORSINGSVRAAG EN DOELWITTE}

Hierdie artikel bied 'n oorsig oor 'n gedeelte van die navorsingstudie wat daarop gerig was om 'n intervensie in groepsverband te ontwikkel vir kinders in hul laat middelkinderjare wat slagoffers is van boeliegedrag. Dit fokus op die tweede fase van intervensie-navorsing, naamlik die insameling en sintese van data. Die primêre fokus was die insameling van data oor die aard van die probleem deur in ' $n$ fokusgroep die menings van professionele persone te verkry om funksionele elemente te identifiseer vir insluiting by die intervensie-program. Vir die verfyning van die intervensieprototipe was dit ook belangrik om die kinderslagoffers van boeliegedrag se stemme te hoor ten opsigte van hoe hulle boeliegedrag ervaar en hanteer. Die insette van die ouers van hierdie deelnemers oor hulle kinders se inskakeling by die toepassing van die prototipe, vorm ook deel van die vroeë ontwikkelings- en voortoetsfase. Data-insameling is aangevul met omvattende literatuurstudie.

Die navorsingsvraag vir hierdie deel van die navorsingstudie was: Wat sal die funksionele elemente wees wat opgeneem sal word in ' $n$ intervensie in groepsverband vir kinders in hul laat middelkinderjare wat slagoffers van boeliegedrag is?

Die relevante doelwitte vir die vermelde fases van intervensienavorsing wat hier beskryf word, is:

- Om ' $n$ eerste fokusgroep te hou met professionele persone (F-deelnemers) wat betrokke is by direkte werk met kinders om hul insette en opinies te verkry ten einde funksionele elemente te identifiseer wat ingesluit kan word by die maatskaplike werk intervensie in groepsverband vir slagoffers van boeliegedrag in hul laat middelkinderjare.

- Om terugvoer te kry van slagofferdeelnemers (S-deelnemers) oor die intervensie en ook van hul ouers (O-deelnemers) ten opsigte van hul kinders se inskakeling by die intervensie

\section{TEORETIESE RAAMWERK}

Volgens die Bio-ekologiese perspektief is daar ' $\mathrm{n}$ wederkerige, voortdurende interaksie en 'n dinamiese verhouding tussen persone en hul omgewing wat die mikro-, meso-, ekso-, makroen chrono-sisteme insluit (Bronfenbrenner \& Evans, 2000:120; Hong \& Espelage, 2012:311-317; Rosa \& Tudge, 2013:251-256; Swart \& Bredenkamp, 2009:407-407; Tudge et al., 2009: 
200-202, 207). Bronfenbrenner se perspektief het sedert 1973 ontwikkel van 'n ekologiese na 'n bio-ekologiese perspektief (Rosa \& Tudge, 2013:243). Vanuit die Bio-ekologiese perspektief (1993-2006) word persoonlike, proses-, konteks- en/of sisteemen tydsfaktore vermeld wat menslike ontwikkeling beïnvloed. Persoonlike faktore sluit onder meer temperament, emosionele en gedragseienskappe en persoonlikheid in. Prosesfaktore dui op die dinamiese interaksie tussen ontwikkelende persone en hul konteks wat families, skole en portuurgroeplede kan insluit en ook bekend staan as proksimale prosesse. Laastens word die tydsfaktor in die konteks van ontwikkeling as beduidend gesien omdat dit dui op die persepsie dat die persoonlike, proses en konteksfaktore nie staties is nie, maar met verloop van tyd verander (Rosa \& Tudge, 2013:251-256; Tudge et al., 2009: 200-202, 207).

Vanuit die Bio-ekologiese perspektief is dit duidelik dat slagoffers van boeliegedrag se ontwikkeling, funksionering en ook hantering van boeliegedrag deur verskillende sisteme beïnvloed word. Hong en Espelage (2012: 311-322) ondersoek in sisteem-verband risikofaktore wat verband hou met boeliegedrag. 'n Bykomende teoretiese begronding wat insig kan bied in die dinamika van boeliegedrag, is die Sirkel van Hoop-model wat reeds verskeie jare binne die Suid-Afrikaanse welsynsisteem gebruik word om sorgplanne vir kwesbare kinders te ontwikkel. Dit word gesien as 'n model vir positiewe ontwikkeling van die jeug en is gebaseer op Amerikaanse opvoedkunde en kinderopvoedkundige filosofieë wat inheemse wysheid integreer met navorsing oor veerkragtigheid en sterkpunt-gebaseerde strategieë (Brendtro et al., 2010:5; Espiner \& Guild 2012:580). Soos die sterkpuntbenadering, beklemtoon die Sirkel van Hoop-model kinders se potensiaal om veerkragtig te wees ten spyte van hul omstandighede (Brokenleg, 2010:10-11; Van Bockern \& McDonald, 2012:14). Brendtro et al. (2005:130), Brendtro en Du Toit (2005:47), Edmondson en Zeman (2011:35-38) en Van Bockern en McDonald (2012:13-17) omskryf universele behoeftes, naamlik om te behoort; te bemeester; om bevoeg en sorgsaam te wees. Edmondson en Zeman (2011:35-38) en Van Bockern en McDonald (2012:14) beklemtoon die belangrike rol en verantwoordelikhede van skoolomgewings in die bevrediging van vermelde universele behoeftes. Van Bockern en McDonald (2012:14) meen dat wanneer skoolomgewings kinders nie die geleentheid bied vir die bevrediging van universele behoeftes nie, dit nie sinvolle leeromgewings is nie en selfs toksiese elemente kan hê.

Die vier basiese behoeftes van die Sirkel van Hoop-model hou verband met die fundamentele menslike behoeftes soos bespreek in die historiese werk van Max-Neef (1991). Max-Neef (1991:8) se model van menslike ontwikkeling fokus op die ontwikkeling van menslike kapitaal wat die bevrediging van fundamentele menslike behoeftes insluit en die bevordering van menslike vermoëns om op hulleself te kan staatmaak. Hierdie behoeftes ten opsigte van die self, sosiale groepe en die omgewing, soos hieronder bespreek, kan op verskillende vlakke en intensiteit bevredig word en sal afhang van verskillende kontekste, tyd, plek en omstandighede (MaxNeef, 1991:18-19; Cruz et al., 2009:2023-2024). Blootstelling aan boeliegedrag kan enersyds die bevrediging van fundamentele behoeftes negatief raak, en andersyds, blyk dit dat sinvolle bevrediging van fundamentele menslike behoeftes beskerming bied omdat dit groter weerbaarheid skep teen die aanslae van boeliegedrag. Max-Neef (1991:49) dui aan dat nie een van die fundamentele behoeftes as meer of minder belangrik as enige ander is nie en hoef ook nie in 'n spesifieke volgorde bevredig te word nie. Menslike behoeftes moet dus sistemies verstaan word. Max-Neef (1991:18-19) identifiseer die volgende fundamentele menslike behoeftes: bestaansmiddele, beskerming, toegeneëntheid, begrip, deelname, identiteit, rus en ontspanning, kreatiwiteit en vryheid. Max-Neef (1991:18-19) is van mening dat die gebrek aan voorsiening in die bogenoemde behoeftes kan lei tot verarming en belemmering van welsyn, wat weer lei tot patologie (Max-Neef, 1991:19, Cruz et al., 2009:2024). Sekere behoeftes wat deel vorm van die Sirkel van Hoop-model en fundamentele menslike behoeftes hou verband met mekaar en word diagrammaties voorgestel in Figuur 1. 
Figuur 1: Integrasie van die Sirkel van Hoop-model en fundamentele menslike behoeftes

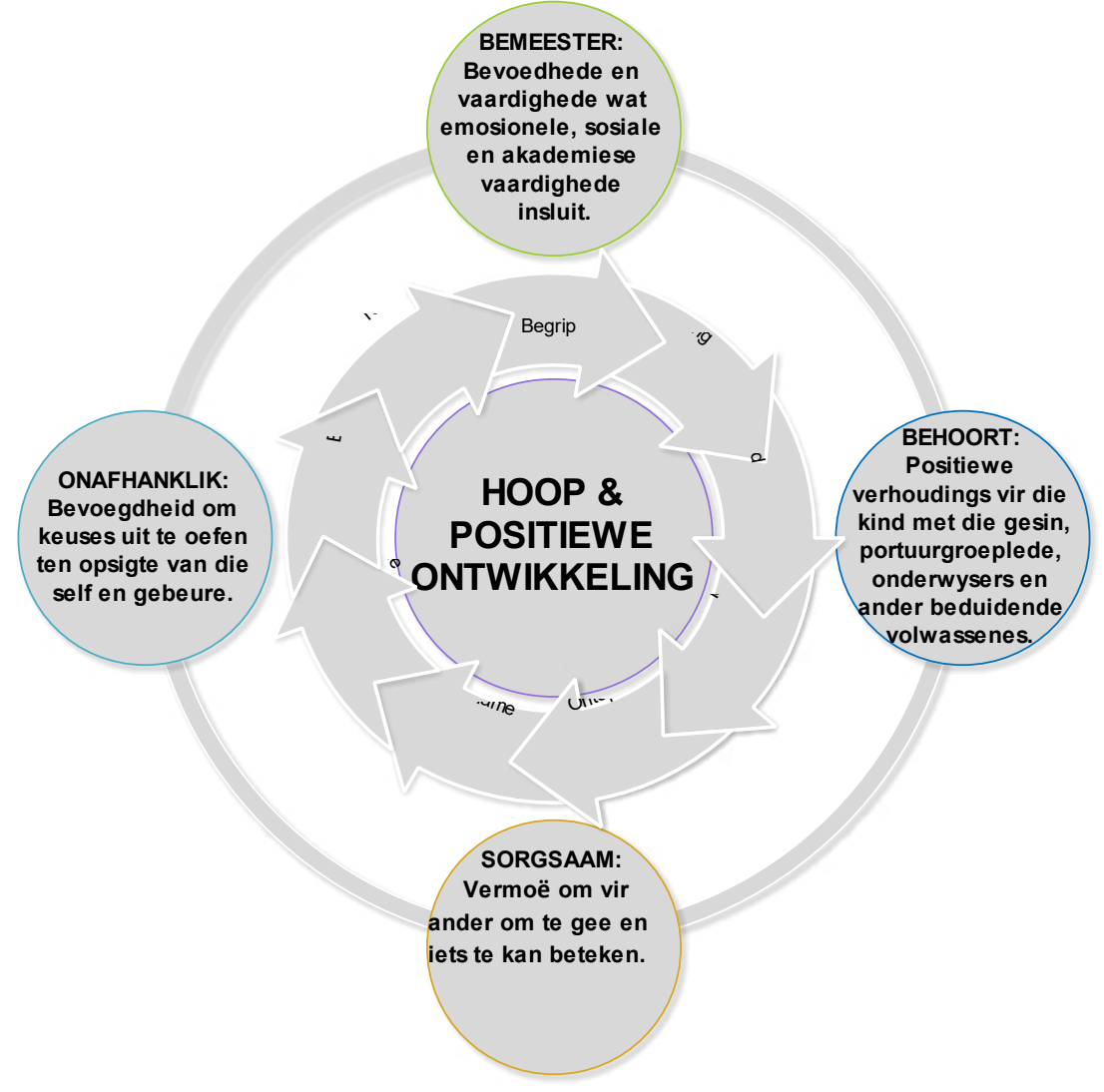

Uit Figuur 1 is dit duidelik dat indien daar nie in sekere fundamentele of universele behoeftes voorsien word nie, of die bevrediging van behoeftes belemmer word, en dit kan daartoe lei dat kinders hopeloos voel en nie tot hul volle potensiaal ontwikkel nie. By kinders wat geboelie word, is dit duidelik dat behoeftebevrediging op verskillende wyses benadeel kan word. Die Sirkel van Hoop-model en fundamentele menslike behoeftes bied 'n goeie onderbou om slagoffers van boeliegedrag te bemagtig, met die fokus op die aanleer van sekere emosionele en sosiale vaardighede asook die versterking van die sin van self, en om potensiaal te ontwikkel. Keyes (2007:97-98) en Lamers et al. (2011:99-100) dui menslike emosionele, sielkundige en sosiale welsyn op ' $n$ welstandskontinuum aan, met patologie aan die een kant en florering aan die ander. Volgens hulle behels negatiewe ervarings risikofaktore wat tot patologie kan lei. In die lig van die negatiewe effek van boeliegedrag op kinders in die geheel, is dit volgens die Sirkel van Hoop-model, fundamentele menslike behoeftes en die welstandskontinuum duidelik dat boeliegedrag 'n risikofaktor is wat positiewe funksionering bedreig.

\section{NAVORSINGSMETODOLOGIE}

Vir hierdie studie is van intervensie-navorsing gebruik gemaak gebaseer op die sogenaamde D \& D (Design and Develop) -model, oorspronklik ontwikkel deur Rothman en Thomas (1994). Hierdie artikel fokus hoofsaaklik op die data-insameling en sintese, die tweede fase van intervensie-navorsing (De Vos \& Strydom 2011:474; Fraser \& Galinsky 2010:1-3; Gilgun
\& Sands 2012:355-366; Rothman \& Thomas 1994:27-39). 'n Literatuurstudie (Fox \& Bayat 2007:35; Whittaker 2012:2425) en fokusgroep (Bhattacherjee 2012:40; Greeff 2011:360-375; Whittaker 2012:50-65) is gebruik om funksionele elemente te identifiseer vir insluiting. Met die toepassing van die prototipe op kinders in hul laat middelkinderjare wat slagoffers is van boeliegedrag (S-deelnemers), was dit duidelik dat hul sienings ook van belang is en dit word hier ingesluit.

Die deelnemers aan 'n fokusgroep (F-deelnemers), die groepwerkprogram (S-deelnemers) en die ouers van S-deelnemers (O-deelnemers) se direkte woorde word weergegee om sienings oor boeliegedrag beter te verstaan (Bhattacherjee, 2012:103; Howitt, 2010:41-43; Whittaker, 2012:9) en met literatuur te kontroleer.

\subsection{Data-insameling en die deelnemers}

Die fokusgroep het bestaan uit ses deelnemers (F-deelnemers) wat almal professionele persone was wat direk met kinders werk. Dit het maatskaplike werkers, ' $n$ berader en opvoedkundige sielkundige ingesluit. Agt S-deelnemers het ingeskakel by die toepassing van die intervensie-prototipe. Hulle moes: (a) afkomstig wees van 'n spesifieke dorp in die Suid-Kaap; (b) tussen nege en twaalf jaar oud wees; (c) Afrikaanssprekend wees (sodat groeplede mekaar kon verstaan); (d) van manlike of vroulike geslag wees; en (e) meer as een keer slagoffers van boeliegedrag gewees het.. Die biografiese besonderhede van S-deelnemers word in Tabel 1 uiteengesit. 
Tabel 1: Biografiese besonderhede van die S-deelnemers

\begin{tabular}{|l|l|l|l|}
\hline S-deelnemer & Geslag & Ouderdom en skoolgraad & Versorgingsposisie \\
\hline 1. & Manlik & 12 jaar, Graad 6 & $\begin{array}{l}\text { Woon by biologiese moeder, ouers van mekaar } \\
\text { vervreem. }\end{array}$ \\
\hline 2. & Manlik & 12 jaar, Graad 7 & Woon by getroude biologiese ouers. \\
\hline 3. & Manlik & 9 jaar, Graad 3 & $\begin{array}{l}\text { Ouers is geskei, het eers by biologiese moeder } \\
\text { gewoon en daarna by biologiese vader. }\end{array}$ \\
\hline 4. & Vroulik & $\begin{array}{l}12 \text { jaar, herhaal Graad 3 en het Graad } \\
\text { herhaal. Is op 'n laat ouderdom } \\
\text { skooltoe. }\end{array}$ & \begin{tabular}{l} 
In pleegsorg. \\
\hline 5.
\end{tabular} \\
\hline 6. & Vroulik & 12 jaar, Graad 7 & Woon by getroude biologiese ouers. \\
\hline 7. & Vroulik & $\begin{array}{l}12 \text { jaar, herhaal Graad 5 } \\
\text { Manlik }\end{array}$ & $\begin{array}{l}9 \text { jaar, Graad 3 } 6 \\
\text { In pleegsorg. }\end{array}$ \\
\hline
\end{tabular}

\subsection{Data-analise}

Die fokusgroep- en groepsessie-data is getranskribeer en geanaliseer volgens die ses fases van tematiese data-analise, beskryf deur Whittaker (2012:92-107), Braun en Clarke (2006:87-93) en Clarke en Braun (2013:4). Hierna het die navorser temas gedefinieer en neergeskryf deur die kern van elkeen vas te lê. Nadat daar op die finale temas besluit is, is die beskrywing daarvan in die finale fase gedoen, soos later beskryf word.

\section{ETIESE OORWEGINGS}

Die navorsers is as maatskaplike werkers ingevolge hulle beroepsgroep gebonde aan die etiese kode van die SuidAfrikaanse Raad vir Maatskaplike Diensberoepe, soos uiteengesit in beleidsriglyne vir maatskaplike werkers (South African Council for Social Service Professions: s.a.). Hierdie dokument word deurgaans as riglyn vir algemene professionele optrede benut.

Etiekriglyne soos beskryf deur Brinkmann en Kvale (2008: 263-293), Strydom (2011:113-129) en Whittaker (2012:33, 114-115) is deurgaans toegepas. Etiese klaring is by die universiteit verkry waar die eerste outeur as student geregistreer was. Toestemming is ook by die Wes-Kaapse Departement van Onderwys verkry. Alle fokusgroepdeelnemers is praktiserende professionele persone wat werk met kinders wat aan negatiewe lewensituasies blootgestel word. Daar is dus nie voorsien dat hierdie groep benadeel sou word deur hulle deelname aan die fokusgroep nie. Die fokusgroepdeelnemers is ingelig oor die doel van die fokusgroep, dat deelname vrywillig was en dat hul kon onttrek indien hulle so sou verkies. Deelnemers se identiteit is te alle tye vertroulik hanteer en ingesamelde inligting is op 'n eties-korrekte wyse hanteer en bewaar.

Die inskakeling van kinders by navorsingstudies vereis spesiale etiese oorwegings omdat hulle ' $n$ kwesbare groep is. Die ouers en kinders is as potensiële deelnemers vooraf ontmoet om die aard en doel van die navorsingstudie te verduidelik, hoe inligting ingesamel sou word en dat die sessies opgeneem sou word. Die vertroulike hantering van inligting en die weerhouding van identiteit is ook verduidelik. Die ouers en kinders is verseker dat hulle op enige stadium deelname aan die studie kon termineer. Die ouers en kinders kon dus ingeligte toestemming verleen vir deelname aan die navorsingstudie.

Vier S-deelnemers $(2,4,7$ en 8$)$ is verwys vir bykomende individuele terapeutiese intervensie. Ses maande ná afloop van die sessies is die kinders individueel gesien vir evaluering van die program en semi-gestruktureerde onderhoude is met die ouers gevoer. Temas is na aanleiding van die F-deelnemers, $\mathrm{S}$-deelnemers en O-deelnemers se insette geïdentifiseer en word vervolgens bespreek.

\section{BEVINDINGS}

\section{Tema 1: Faktore wat die ervaring en hantering van boeliegedrag beïnvloed}

Die persepsie bestaan dat boeliegedrag ' $n$ "normale deel van grootword" is, "kinders sterker maak", "karakter bou" en "kinders voorberei op die lewe daarbuite" 
(Ancer, 2009:7; Dussich \& Machoya, 2007:495; Rigby, 2007:48; Vaillancourt et al., 2010:301). Maar boeliegedrag word ook beskou as 'n ernstige sosiale probleem wat veral in primêre en sekondêre skole voorkom en onrusbarende gevolge kan hê (Greeff \& Grobler, 2008:127; Rigby, 2012:17-18; Swearer et al., 2009:17, 28-38; Vaillancourt et al., 2010:293). Rigby (2007:49) beklemtoon egter dat in sekere gevalle slagoffers relatief skadeloos daarvan kan afkom, afhangende van hul veerkragtigheid en ander lewensfaktore. Verskillende faktore is deur die fokusgroep aangedui wat die ervaring en hantering van boeliegedrag beïnvloed. Hierdie inligting word aangevul met inligting soos weergegee deur die S-deelnemers en O-deelnemers.

\section{Individuele faktore}

Waar kinders van ander verskil ten opsigte van fisieke of persoonlike eienskappe, verstandelike vermoëns of sosiale vaardighede, kan dit daartoe lei dat hulle slagoffers van boeliegedrag word (Ancer, 2009:7). S-deelnemers identifiseer byvoorbeeld beperkte akademiese vermoëns as 'n rede wat daartoe bydra dat hulle geboelie word: "Ek is te dom en kan nie leer nie" (S-deelnemer 1). Weens hul fisieke voorkoms word kinders ook geterg en gespot: "vet en stadig" (S-deelnemer 3), "hare kort ... en tone wat snaaks is" (S-deelnemer 4), "oë wat skeel is en omdat ek vet is" (S-deelnemer 5). Ander redes vir viktimisering is: omdat hulle "met meisies speel" (S-deelnemer 1), "op my senuwees is" (S-deelnemer 2) en "teruggetrokke is" (S-deelnemer 7). S-deelnemers se menings stem ooreen met die ouers se persepsies van die redes wat daartoe bydra dat kinders geboelie word naamlik:

"Hy's kompeterend. Hy wil altyd die laaste sê hê. Hy wil altyd die middelpunt van aandag wees in 'n speelsituasie. Hy glo nie aan verloor nie. Hy is altyd reg. Hy is baie dominerend. Hy het wonderlike leierseienskappe, maar daai karaktereienskappe penaliseer hom ongelukkig" (O-deelnemer 8).

"Sy is oorgewig" (O-deelnemer 7).

Dit is duidelik dat fisieke kenmerke, temperament en intellektuele aspekte wat verskil van die norm, kinders kan blootstel aan boeliegedrag.

\section{Betrokkenheid en ondersteuning van maats, ouers en onderwysers}

Die sosiale ondersteuning aan slagoffers in die mikro-sisteem deur ouers, onderwysers en portuurgroeplede kan gesien word as ' $n$ beskermende faktor wat die uitwerking van boeliegedrag op verskillende vlakke minder ernstig en meer hanteerbaar kan maak (Murray-Harvey et al., 2010:42; Patton et al., 2013:255; Rothon et al., 2011:586; Yeung \& Leadbeater, 2010:95-96).

Van besondere belang is die hantering van boeliegedrag deur onderwysers en ook omstanders wat beïnloed word deur die skoolkultuur, skool-etos en skoolklimaat, omdat dit sekere waardes, norme, en houdings omsluit ten opsigte van die leerders se gedrag, onderling teenoor mekaar en teenoor onderwysers (Rigby, 2007:94). Volgens Barnes en De
Wet (2012:79), Eliot et al. (2010:549-550), Hong en Espelage (2012:316-317), MacDonald en Swart (2004: 33), Rigby (2007:94108), Rigby (2012:112-115) en Sullivan (2006:25) bepaal die skoolkultuur die aard van verhoudings in die skool, wat weer ' $n$ invloed het op die voorkoms, aard en instandhouding van boeliegedrag.

S-deelnemers maak dit duidelik dat hulle dikwels, wanneer hulle geboelie word, staatmaak op die hulp of ondersteuning van onderwysers:

S-deelnemer 8 "sê vir juffrou" wanneer hy geboelie word. Wanneer alternatiewe wyses vir die hantering van boeliegedrag ondersoek word, identifiseer S-deelnemer 1 die volgende opsie: "kan vir meneer gaan sê", en S-deelnemer 2 beplan "om vir 'n goeie juffrou te gaan sê". S-deelnemer 5 "moet vir die onderwyser vra of sy na die badkamer kan gaan en daar gaan huil", en S-deelnemer 7 sal "toestemming kry om die klas te verlaat" en "meneer sal verstaan omdat hy trane in jou oë sien".

Dit is dus duidelik dat onderwysers se ingesteldheid, houdings en perspepsies ' $n$ beduidende impak gaan hê op die wyse waarop hulle boeliegedrag gaan benader en hanteer. Die navorser stem saam met De Wet (2013:8) en Van der Walt (2012:1) dat onderwysers se roepingsbewustheid beslis die hantering van kinders en situasies in die skool sal beïnvloed. Indien onderwysers dus hul taak en verantwoordelikheid ten opsigte van kinders wie aan hulle toevertrou is as ' $n$ God-gegewe roeping sien, is die waarskynlik groter dat hulle boeliegedrag met meer erns, sensitiwiteit en verantwoordeliheid sal hanteer.

Verder word omstanders se houding, betrokkenheid en moontlike ondersteuning aan boelies beklemtoon, wat 'n beduidende rol kan speel in die voorkoms, aard en hantering van boeliegedrag. Omstanders se houdings en reaksies kan daartoe lei dat boeliegedrag aangemoedig of gestuit kan word (Rigby, 2012:21-22; Swearer et al., 2009:17-19; Sullivan, 2011:3538; Themlow et al., 2010: 73-80).

F-deelnemers het aangedui dat slagoffers van boeliegedrag nie in isolasie gehelp kan word nie. F-deelnemers 2, 3 en 5 is van mening dat die deurlopende betrokkenheid en ondersteuning van betekenisvolle persone noodsaaklik is, en F-deelnemer 1 stel dit so:

"Deel van die program is om ouers of ander rolspelers of onderwysers, familie of maats te betrek, dat mens die hele sisteem betrokke begin kry, want hulle gaan aan die einde van die dag moet aanhou om die kind te ondersteun".

Uit bogenoemde is dit duidelik dat ondersteuning aan slagoffers van boeliegedrag ' $n$ belangrike element is in die konteks van hulpverlening. Dit is veral belangrik, gegewe die ontwikkelingstadium (laat midddelkinderjare), om portuurgroepe te mobiliseer sodat slagoffers se gevoel van isolasie verminder word. Groepwerk bied dus besondere moontlikhede vir die ondersteuning van slagoffers van boeliegedrag. 


\section{Tema 2: Moontlike programinhoud van groepintervensie}

Vanuit die praktyk en literatuur is dit duidelik dat slagoffers wat herhaaldelik blootgestel word aan boeliegedrag nie noodwendig oor die nodige vaardighede, vermoë, selfvertroue of ondersteuning beskik om die boelie-situasies en emosies wat daarmee verband hou, te kan hanteer nie (Crothers \& Kolbert, 2010:539-540; Rigby, 2012:17-18; Sullivan, 2011:3-7,16, 34-35; Swearer et al., 2009:17).

\section{Hulp met die hantering van emosies}

Wanneer kinders blootgestel word aan boeliegedrag, word negatiewe emosies ervaar soos hartseer, woede, skaamte, skuldgevoelens en gemoedskommelings (Hansen et al., 2012:384; Neser, 2006:138, Rigby, 2007:251-253; Yeung \& Leadbeater, 2010:94). Negatiewe emosionele ervarings kan lei tot ernstige gevolge soos angs, depressie, selfdoodgedagtes en selfdood (Nel, 2016:19; Rigby, 2012:17; Rothon et al., 2011:586; Swearer et al., 2009:54, 64, 98). Vanuit die navorsingsessies identifiseer S-deelnemers die volgende emosies: "kwaad" (S-deelnemers 1, 2, 3, 4, 6, 7 \& 8), "woedend" (S-deelnemer 5), "hard woedend" (S-deelnemer 3), "gefrustreerd" (S-deelnemer 8), "uitbarstings" (S-deelnemer 4), "gestres en bekommerd" (S-deelnemer 2), "mal en weet nie wat om te doen nie" (S-deelnemer 6), "bang" (S-deelnemer 4) en laastens "hartseer" (S-deelnemers 1, 3, 4, 5, 6, 7, 8). Hulle het aangedui dat dit soms help om vir iemand van hierdie situasies te vertel: "juffrou... werk partymaal" (S-deelnemer 3) of "moeder... sê dat ek van boelies moet wegbly" (S-deelnemer 4). Sommige hanteringswyses kan situasies egter vererger, soos: "huil" (S-deelnemer 2, 7), "weghardloop" (S-deelnemer 6), "slaan die boelie dat hy vlieg" (S-deelnemer 7) en "stamp kinders of sê iets aspris vir kinders" (S-deelnemer 8).
Literatuur bevestig die waarde van konstruktiewe hantering van emosies - ook beskou as een van die bevoegdhede van emosionele bevoegdheid - as 'n belangrike aspek wat by intervensie vir slagoffers van boeliegedrag ingesluit moet word (Espelage et al., 2009:98-99, Frey et al., 2010:405; Orphinas \& Horne, 2010:54-55; Sullivan, 2011:238). Hulp met die hantering van emosies is soos volg deur die F-deelnemers bevestig as 'n belangrike fokuspunt:

"Of mens moet begin met die individu op emosionele vlak" (F-deelnemer 5).

"Ek dink dit is waar mens sal begin met die emosies en dat mens die kind bewus maak van sy emosies dan kan jy van daar af aangaan en vir hom leer wat om dan met die emosies te doen ... dis mos in elke geval jou emosies wat jou gedagtes en jou gedrag bepaal en laasgenoemde bepaal weer jou emosies. So ek dink mens dit maar in daai volgorde ook doen" (F-deelnemer 5).

Volgens die Gestalt-benadering moet die bewustheid van emosies beklemtoon word alvorens die hantering van emosies aandag kan geniet (Clarkson, 2004:44; Oaklander, 1988:189; Yontef \& Jacobs, 2008:330-331). In dié verband beklemtoon F-deelnemer 6 datditvirslagoffersvan boeliegedrag noodsaaklik is om bewus te wees van hul emosies wanneer hulle blootgestel word aan boeliegedrag: Dit blyk dus uit literatuur en bydraes van deelnemers dat bewustheid en die algemene hantering van emosies komponente van die intervensie moet wees. In dié verband word ook verwys na die Gestalt siklus van bewustheid wat bewustheid en kontak beklemtoon om interne of eksterne behoeftebevrediging moontlik te maak. Die verskillende fases van hierdie siklus word soos volg diagrammaties voorgestel in Figuur 2, gegrond op die werk van verskeie outeurs (Clarkson, 2004:37-43; Reynolds \& Mortola, 2005: 159-162, 170-174). 
Figuur 2: Die siklus van bewustheid

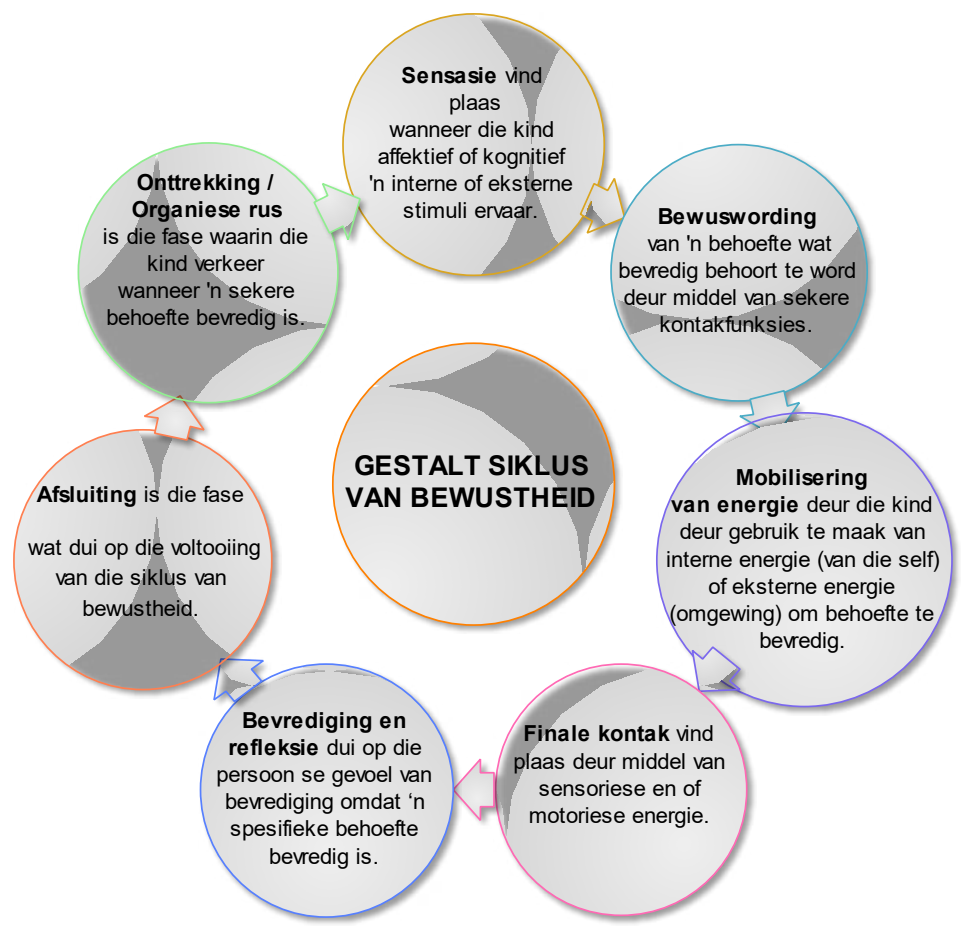

By goedaangepaste kinders wie se funksionering nie gestrem of negatief beïnvloed is nie en wat hul eie behoeftes bevredig deur die gebruik van interne (van die self) en eksterne energie (vanuit die omgewing), verloop die Gestalt-siklus van bewustheid in 'n proses van homeostase of selfregulering (Oaklander, 2007:13; Reynold \& Mortola, 2005:159-162; Yontef \& Jacobs, 2008:227, $337-338,343$ ) soos hierbo voorgestel. Dit is reeds duidelik dat boeliegedrag 'n beduidende effek kan hê op funksionering, wat heel moontlik kinders se behoeftebevrediging kan strem. Dit is dus noodsaaklik dat die hantering van behoeftebevrediging in die intervensie ingebou word om boelieslagoffers bewus te maak van alternatiewe toepaslike wyses van behoeftebevrediging.

\section{Versterking van die selfbeeld}

Anderson (2012:17), Crothers en Kolbert (2010:539-540), Espelage etal. (2009:98), Rigby (2012:52-53) en Thomas (2012:34) beklemtoon die opbou van die selfbeeld van boelieslagoffers in die konteks van intervensie. Garandeau et al. (2010:119) en Louw en Louw (2007:42) se menings stem ooreen met Davies (2011:340) wat beklemtoon dat kinders se selfbeeld grotendeels sal afhang van akademiese, sosiale en fisieke bevoegdhede en ook fisieke voorkoms. Kinders se persepsies dat hulle byvoorbeeld gewild is en dat maats van hulle hou, kan dus bydra tot ' $n$ verhoogde selfbeeld. Rigby (2007:51) en Sullivan (2006:72) dui aan dat slagoffers van boeliegedrag die boodskap ontvang dat hulle ongewild is en hierdie terugvoer het dus 'n negatiewe uitwerking op hul selfbeeld.

In die konteks van die Sirkel van Hoop-model en fundamentele menslike behoeftes, word die behoeftes om te behoort (aan sosiale groepe of 'n vriendekring) beïnvloed asook vryheid (om op enige plek op skoolgronde te kan speel of wees sonder die vrees om geboelie te word); toegeneëndheid (om met sensitiwiteit en positiewe affek hanteer te word); begrip (om onvoorwaardelik aanvaar en verstaan te word); deelname (aan klas-, sosiale en ontspanningsaktiwiteite sonder om geboelie te word) en identiteit (om die ware self te kan wees sonder om daaroor geboelie te word). In die konteks van die Gestalt benadering, is die versterking van die self van kinders ook deur $F$-deelnemer 2 aangedui as ' $n$ belangrike aspek van intervensie:

"Dit sal dan outomaties die eerste stap wees, want die kind gaan so sleg in homself voel as hy by jou aankom, dat as jy hom nie eers bietjie ge-'affirm' het en eers sy eie self ' $n$ bietjie opgehef het nie, gaan jy glad nie kan begin met die gedragsmodifikasie op die ou einde nie".

Dit is dus duidelik dat die verbetering van selfvertroue, die selfbeeld en die sin van die self nie beskou kan word as 'n spesifieke strategie vir hulpverlening nie, maar eerder as ' $\mathrm{n}$ integrale komponent wat regdeur die hulpverlening beklemtoon word.

\section{Sosiale vaardighede}

Wanneer kinders geboelie word en hul sosiale verhoudings nie positief ervaar nie, kan hulle op verskillende wyses hierop reageer, met wisselende gevolge. (Garandeau et al., 2010:119; Georgiou \& Stavrinides, 2008:583; Olweus, 2010:14; 584; Sullivan, 2006:98-99; Twemlow et al., 2010:2010). Slagoffers kan hulle onttrek en isoleer van portuurgroeplede en nie meer bereid wees of die vrymoedigheid hê om vriende te maak nie en dus eensaamheid ervaar. Die gevolg kan wees dat hulle minder sosiale ondersteuning en beskerming teen 
boelie-situasies het (Marais \& Meier, 2010:51; Neser 2006:141). Volgens die Sirkel van Hoop-model kan isolasie en onttrekking daartoe lei dat slagoffers weerhou word van geleenthede om te kan behoort aan spesifieke groepe en om interpersoonlike en sosiale vaardighede aan te leer en te bemeester (Brokenleg, 2010:10-11; Van Bockern \& McDonald, 2012:14). Slagoffers kan 'n meer introspektiewe leefwyse begin handhaaf waarvan lees en studeer 'n belangrike deel uitmaak, sodat die handhawing van sosiale verhoudings vir slagoffers minder belangrik word. Dit kan bydra tot goeie akademiese prestasies, maar kan kinders ook weerhou van geleenthede om belangrike sosiale vaardighede te ontwikkel juis omdat hulle nie betrokke is in verhoudings met portuurgroeplede nie (Rigby, 2007:54). Hierdie geïsoleerde leefwyse kan hulle weerhou van geleenthede en die vrymoedigheid om sorgsaam te kan wees.

Dit is dus volgens die Sirkel van Hoop-model en fundamentele menslike behoeftes duidelik dat blootstelling aan boeliegedrag 'n sosiale stressor is wat as gevolg van die effek op sosiale verhoudings direk of indirek kan inmeng met die bevrediging van ontwikkelingsbehoeftes (sien Figuur 1).

Die S-deelnemers se verwysing na wyses hoe hulle boeliegedrag hanteer sluit die volgende in: "vloek hom en slaan hom ... en slaan terug" (S-deelnemer 1), "slaan almal wat voorkom ... wil ek sommer iemand doodmaak" (S-deelnemer 2), "slaan sommer enige een en loop, ruk ek my op" (S-deelnemer 6), en "maak ek of ek dit nie voel nie, as ek by die huis kom dan voel ek dit" (S-deelnemer 3). Die bogenoemde wyses dui daarop dat hulle die aanleer van sosiale en ander vaardighede nodig het om boelie-situasies meer effektief te hanteer.

Espelage et al. (2009:98-99), Orpinas en Horne (2010:55-56), Rigby (2012:55) en Thomas (2012:37) dui vaardighede aan wat slagoffers in staat sal stel om sosiale situasies beter te hanteer, naamlik verbale, algemene vriendskaps-, selfgeldings-, kommunikasie- en empatiese vaardighede. Volgens F-deelnemers is die aanleer en inoefening van spesifieke vaardighede wat selfgeldende gedrag insluit, 'n moontlike strategie om slagoffers te bemagtig om situasies beter te hanteer:

"Moet definitief 'n kognitiewe komponent wees in die sin van 'n stukkie struktuur wat ... bepaalde vaardighede insluit wat mens moet inoefen" (F-deelnemer 3).

"Om regtig net vaardighede in te begin oefen, konflikhantering, selfgelding en kommunikasie" (F-deelnemer 5).

“Dat dit nie noodwendig boeliegedrag [is] wat die primêre probleem is nie, maar gewoonlik net selfgelding. As jy kinders met selfgeldings probleme het, is dit baie keer dat boeliegedrag of dat die kind geboelie word, 'n dimensie [is] daarvan" (F-deelnemer 3).

\section{Tema 3: Uitdagings en moontlike struikelblokke}

Volgens F-deelnemers is dit duidelik dat daar uitdagings en struikelblokke is wat daartoe bydra dat boeliegedrag nie noodwendig ' $n$ prioriteit is in die konteks van maatskaplike werk met kinders in gesinsorgorganisasies nie en hierdie kwessie word vervolgens bespreek.

\section{Werkslading van professionele persone}

F-deelnemers het laat blyk dat professionele persone se groot werksladings dit moeilik maak om werklik aandag te skenk aan kinders wat geboelie word.

"Dis nou maar 'n realiteit. Veral by gesinsorganisasies waar jy met 250 kinders sit, of selfs meer, jy kan nie by die slagoffers uitkom nie, jy hanteer net krisisse en jy is nie daar om die gevolge van trauma te hanteer of selfs om vir 'n kind weerbaar te maak ... nie" (F-deelnemer 2).

“... die veiligheids- en fisiologiese behoeftes kom eerste en daarmee stem ek saam ... mens gaan dit eerste moet hanteer voordat jy kan uitkom by emosionele behoeftes van slagoffers van boeliegedrag" (F-deelnemer 5).

F-deelnemers besef duidelik die erns van boeliegedrag, maar kan weens hul werkslading nie die nodige aandag skenk aan slagoffers van boeliegedrag nie.

\section{Bewustheid van probleme word te laat ervaar en aanmelding is dus nie vroeg genoeg nie}

Slagoffers rapporteer nie altyd boeliegedrag aan ouers en/ of onderwysers nie. Die volgende aspekte is moontlik redes hiervoor volgens De Lara (2012:293-301), Eliot et al. (2005:219222), Rigby (2012:10) en Sullivan $(2011: 23,116)$, naamlik dat slagoffers:

- Onder die indruk verkeer dat volwassenes nie iets daaraan kan doen nie (moontlik uit vorige ervarings).

- Bang is hulle word nie geglo, ernstig opgeneem of na geluister nie.

- Vrees boeliegedrag sal vererger omdat hulle iemand daarvan vertel het.

- $\quad$ Bang is volwassenes sal oorreageer.

- Skaam voel daaroor dat hulle geboelie word en ook omdat hulle nie self in staat is om boeliesituasies te hanteer nie.

In lyn met bogenoemde meld die F-deelnemers die volgende:

"Met boeliegedrag is ouers baie keer die laaste wat weet hulle kinders word geboelie of omdat die kindertjies so ge-'train' is om dit weg te steek" (F-deelnemer 5).

"Maar dis min dat die ouers kom en sê: my kind word geboelie" (F-Deelnemer 3).

S-deelnemers het genoem hulle vertel nie vir hul ouers wanneer hulle geboelie word nie "want partykeer vertrou jy nie jou ouers nie, of jy dink hulle gaan jou skel of hulle dink jy lieg" 
(S-deelnemer 7). Dit is dus duidelik ouers is dikwels nie bewus hul kinders is slagoffers van boeliegedrag nie en nie altyd toepaslik reageer nie, of eers bewus raak daarvan wanneer die effek op hul kinders reeds duidelik sigbaar is.

\section{Tema 4: Konteks waarin hulpverlening sou kon plaasvind}

Olweus se skoolgebaseerde intervensie-program, Olweus Bullying Prevention Programme (OBPP), sluit intervensie in op die individuele vlak, skoolvlak, in die klaskamer (De Wet, 2007:196-197; Olweus \& Limber, 2010:377-381; Protogerou \& Flisher, 2012:124-126; Rigby, 2012:45; Ttofi et al., 2008:48-49) en op gemeenskapsvlak (Olweus \& Limber, 2010:383). Hierdie program word in die buiteland gebruik en hoewel dit op verskillende vlakke fokus, vermeld dit nie of dit as intervensie ook in groepsverband aangewend kan word nie. Hierdie navorsing spreek dus daardie gaping aan deur ' $n$ intervensie te ontwikkel vir slagoffers van boeliegedrag in groepsverband, om hulle te bemagtig om die blootstelling aan boeliegedrag meer effektief te hanteer.

\section{In groepsverband}

Die F-deelnemers is ten opsigte van die modaliteit van maatskaplike intervensie van mening dat hulpverlening in groepsverband vir die doel van hierdie spesifieke navorsingstudie vir slagoffers van boeliegedrag tot voordeel kan wees en ook meer koste-effektief. Die F-deelnemers motiveer dit soos volg:

"As mens nou dink aan die ouderdomsgroep waarin hulle is ... sê nou maar om 'n groepie van vyf of ses of wat ook al, saam te laat sit en praat oor as hulle almal geboelie word? Want daardie hele saampraat en sê nou maar ... die CBT [Kognitiewe gedragsbenadering] of een of ander aspek daarvan ... gaan dit nie momentum genereer deurdat hulle ondersteunend raak vir mekaar, dat hulle insigte kry by mekaar ... is dit nie in groepsverband baie meer ekonomies nie, want jy bereik met een sessie vyf kinders?" (F-deelnemer 3).

“Ek dink groepsverband gaan ideaal wees omdat ons [by NGO's] veronderstel is om groepe aan te bied, so dit kan wonderlik wees om vir maatskaplike werkers idees te gee van 'n tipe groep wat jy kan hou, en dan het jy die tyd en spasie om dan die proses te kan deurwerk" (F-deelnemer 2).

"Groepsverband ... gaan meer effektief wees as om dit individueel aan te bied. Jy gebruik die dinamika van die groep" (F-deelnemer 3).

In die konteks van maatskaplike werk word groepwerk deur Hepworth et al. (2013:280), Toseland en Rivas (2012:11-12) en Zastrow (2010:45-46) beskryf as aktiwiteite of prosesse wat ten doel het om verandering teweeg te bring. Hierdie verandering kan die ontwikkeling, groei of aanpassing van individue se sosiale, intellektuele, emosionele vermoëns en gedragsaspekte insluit. Hepworth et al. (2013:282) en Zastrow (2010:79-80) beklemtoon koste-effektiwiteit as een van die belangrikste voordele van maatskaplike werk intervensie in groepsverband.
Een van die voordele wat groepwerk vir lede kan inhou, is wederkerige hulp (mutual aid) wat dui op die omstandighede waar groepslede mekaar van hulp kan wees en ondersteun met persoonlike groei (Drumm, 2006:21; Steinberg, 2010:55, Toseland \& Rivas, 2012:17). Dit is duidelik uit getranskribeerde aanhalings dat S-deelnemers die inskakeling van intervensie in groepsverband as positief ervaar het: "Lekker dat ek met al die maatjies kan speel" (S-deelnemer 7), "Dit voel lekker om dit vir hulle te sê ... en te deel" (S-deelnemer 3), en "Lekker om mekaar te vertrou" (S-deelnemer 7). Die S-deelnemer se ouers (O-deelnemers) se opinies het die volgende ingesluit:

"Nee, ek dink dis 'n goeie ding. Kyk die verandering na die tweede, derde sessie, daar het 'n baie groot verandering gekom" (O-deelnemer 3).

\section{"Die kind is lief vir haar sessies" (O-deelnemer 4).}

"Hy het dit baie geniet, dit was vir hom lekker om te assosieer. Dit was vir my oulik, want dit was die eerste keer dat hy kameraadskap geuiter het. Hy wou kom en dit was vir hom lekker. Dit was vir hom 'n prioriteit gewees so dit was vir my positief. En ek dink dit was vir hom goed om te hoor wat met ander kinders gebeur en om te hoor wat hy moet doen" (O-deelnemer 8).

"Baie voordelig om hulle by te staan, in te lig oor hoe dit hanteer moet word. Die feit dat daar baie ander kinders aan hierdie gedrag blootgestel word. Ondersteun en opbou van die kind se selfvertroue" (O-deelnemer 7).

Kinders in hul laat middelkinderjare wat slagoffers is van boeliegedrag is normaalweg geïsoleerd binne portuurgroepe, juis in 'n ontwikkelingsfase waar portuurgroepe baie belangrik raak. Inskakeling by groepwerk kan dus sinvol wees wanneer dit ook die slagoffers se gevoel van isolasie verminder.

\section{Op individuele vlak}

Rigby (2011:277) verwys na die versterking van slagoffers as 'n moontlike strategie tot intervensie wat fokus op individue se vaardighede om boelie-situasies meer effektief te hanteer. Rigby (2011:277) is ook van mening dat die aanleer van toepaslike vaardighede 'n tydrowende proses kan wees. Swearer et al. (2009:98) dui aan dat slagoffers en ook boelies aandag nodig het op individuele vlak en in groepsverband, om sodoende die sielkundige impak wat depressie, angs en selfdoodgedagtes kan insluit, aan te spreek en te fokus op die verbetering van sosiale vaardighede, algemene welsyn en selfbeeld. Alhoewel die fokusgroep oor die algemeen oorwegend ten gunste van hulpverlening in groepsverband is, stel hulle voor dat individuele sessies ook deel uitmaak van die intervensie: "En [die groep is] ondersteunend en sou dit nodig wees dan neem jy die individu" (F-deelnemer 3). "Of dat mens begin met die individu op emosionele vlak en vir hulle voorberei [vir die inskakeling van intervensie in groepsverband]" (F-deelnemer 6). 


\section{In skole of klaskamers}

Literatuur dui daarop dat die toepassing van intervensie in die konteks van boeliegedrag sou kon plaasvind in skole of in klaskamers wat ooreenstem met kurrikulumgebaseerde intervensie (Crothers \& Kolbert, 2008:137-138; Frey et al., 2010:405-406; Renshaw \& Jimerson, 2012:115-128; Rigby, 2012:xiv, 5, 65-66). Hierdie stelling word ondersteun deur F-deelnemer 3:

"As jy die program sou verder vat, sou jy dit op 'n manier dalk in die skole kon implementeer, want lewensvaardigheid is byvoorbeeld een klas en hulle is oop daarvoor dat onderwysers byvoorbeeld hierdie tipe van goed in die klasse doen sodat dit dan een van die modules sal wees" (F-deelnemer 3).

Die navorser stem saam met Rigby (2007:283) dat verskillende metodes vir die hantering van boeliegedrag nie in isolasie kan plaasvind nie. Hy is van mening dat verskillende metodes vir die effektiewe hantering van boeliegedrag in kombinasie gebruik moet word met 'n skoolgebaseerde benadering.

\section{BESPREKING}

Belangrike aspekte het vanuit die fokusgroep na vore gekom, aangevul met S-deelnemers se stemme ten opsigte van persepsies van boeliegedrag, hoe hulle boeliegedrag ervaar en hanteer, en alternatiewe wyses van hantering soos deur hulle voorgestel. O-deelnemers se opinies en insette is ook verkry rondom hul kinders se inskakeling by die toepassing van die prototipe.

Die blootstelling aan boeliegedrag en die aard daarvan is kompleks en kan nie in isolasie van ander faktore beskou word nie. Die effek van boeliegedrag op slagoffers is beduidend en multidimensioneel en intervensie op verskillende vlakke is nodig.

In die lig van bogenoemde is dit dus duidelik dat daar nie net een program kan wees wat al die verskillende elemente en faktore insluit om die komplekse dinamiese verskynsel van boeliegedrag aan te spreek nie. Verskillende professies met hul spesifieke vaardighede sal by die intervensie ingesluit moet word ten einde 'n omvattende oplossing vir die probleem te vind.

\section{BRONNELYS}

ANCER, J. 2009. Steps to bullyproofing your child. Sunday Times: 7, 6 September.

ANDERSON, G. 2007. The impact of bullying in school on the adolescent's sense of self. Pretoria: UP. (Dissertation - MSD).

BhatTACHerJeE, A. 2012. Social science research. Principles, methods, and practices. 2 Ed. USA: University of South Florida- Anol Bhattacherjee.

BRAUN, V. \& CLARKE, V. 2006. Using thematic analysis in psychology. Qualitative research in psychology, 3:77-101.

BROKENLEG, M. 2010. The resilience revolution: our original collaboration. Reclaiming Youth and Children, 18(4):8-11.

BRONFENBRENNER, U. \& EVANS, G.W. 2000. Developmental science of the $21^{\text {st }}$ century: Emerging questions, theoretical models, research designs and empirical findings. Social Development, 9(1):115-125.

CARTER, J.C., FLANAGAN, K.S. \& CABALLERO, A.B. 2013. Spirituality and peer victimization in early adolescence: Associations within a Christian school context. Journal of Psychology \& Theology, 41(2):150-160.

CLARKE, V. \& BRAUN, V. 2013. Teaching thematic analysis: over- coming challenges and developing strategies for effective learning. The Psychologist, 26 (2):120-123

CLARKSON, P. 2004. Gestalt counselling in action. $3^{\text {rd }}$ ed. London, Thousand Oaks, New Delhi: Sage Publications.

CRAIG, W.M. \& PEPLER, D.J. 2007. Understanding bullying: From research to practice. Canadian Psychology, 48(2):86-93.

CROTHERS, L.M. \& KOLBERT, J.M. 2008. Tackling a problematic behaviour management issue: Teacher's intervention in childhood bullying problems. Intervention in school and clinic, 43 (3), 132-139.

CRUZ, Y., STAHEL, A. \& MAX-NEEF, M. 2009. Towards a systemic development approach: building on the human-scale development paradigm. Ecological Economics, 68:2021-2030.

DAVIES, D. 2011. Child development. A practitioner's guide. $3^{\text {rd }}$ ed. New York: Guilford.

DE VOS, A.S. \& STRYDOM, H. 2011. Intervention Research. (In De Vos, A.S., Strydom, H., Fouché, C.B. \& Delport, C.S.L., eds. Research at grass roots: for the social sciences and human service professions. $4^{\text {th }}$ ed. Pretoria: Van Schaik. p. 473-489.)

DE WET, N.C. 2005. Educator recognition of and intervention in school bullying situations: The perspectives and experiences of free state educators and learners. Acta Criminilogica, 18(2), 44-55.

DE WET, C. 2007. Educators' perspective on bullying prevention strategies. South African Journal of Education, 27(2):191-208.

DE WET, C. 2013. Educators' perspectives on risk factors for learner-on-learner bullying. Koers - Bulletin for Christian Scholarship 78(3), 1-9. http://www. koersjournal.org.za

DE LARA, E.W. 2012. Why adolescents don't disclose incidents of bullying and harassment. In Journal of School Violence, 11:288-305.

DRUMM, K. 2006. The essential power of group work. Social Work with Groups, $29(2-3): 17-31$

DUSSICH, J.P.J. \& MAEKOYA, C. 2007. Physical child harm and bullying- related behaviors: A comparative study in Japan, South Africa and the United States. International journal of offender therapy and comparative criminology, (51)3: 495-509.

EDMONSON, L. \& ZEMAN, L. D. 2011. Making school bully laws matter. Reclaiming Children and Youth, 20(1):33-38.

ELIOT, M., CORNELL, D., GREGORY, A. \& FAN, X. 2010. Supportive school climate and student willingness to seek help for bullying and threats of violence. Journal of School Psychology, 48:533-553.

ESPINER, D \& GUILD, D. 2012. Capturing what matters most. Engaging students and their families in educational planning. Teaching Exceptional Children, May/June: 57-67.

FEKKES, M., PIJPERS, F.I.M. \& FREDERICKS, A.M., VOGELS,T. \& VERLOOVEVANHORICK, S.P. 2006. Do bullied children get ill, or do ill children get bullied? A prospective cohort study on the relationship between bullying and health-related symptoms. Pediatrics: Official Journal of the American Academy of Pediatrics, 117:1568-1574.

FOX, W \& BAYAT, M S. 2007. A guide to managing research. Cape Town: Juta. 
FRASER, M.W. \& GALLINSKY, M.J. 2010. Steps in intervention research. Designing and developing social programmes. Research on Social Work Practice: 459-466.

FREY, K.S., EDSTROM, V. \& HIRSCHSTEIN, M.K. 2010. School bullying. A crisis or opportunity? (In Jimerson, S., Swearer, S. M., \& Espelage, D. L. eds. Handbook of bullying in schools. An international perspective. New York: Routledge. p. 403-415.)

GARANDEAU, C.F., WILSON, T. \& RODKIN, P.C. 2010. The popularity of school bullies in gender and racial conflict. (In Jimerson, S., Swearer, S. M., \& Espelage, D. L., eds. Handbook of bullying in schools. An international perspective. New York: Routledge. p. 119-136.)

GEORGIOU, S.N. \& STAVRINIDES, P. 2008. Bullies, victims and bully-victims: Psychosocial profiles and attribution styles. School Psychology International, 29(5), 574-589.

GILGUN, J.F., \& SANDS, R.G. 2012. The contribution of qualitative approaches to developmental intervention research. Qualitative Social Work, 11(4): 349-361.

GOVENDER, M. 2013. The psycho-educational impact of bullying on primary school learners. UNISA. (Master of Education with specialization in Guidance and Counselling.)

GRECO, L. A., FREEMAN, K.E. \& DUFTON, L. 2007. Overt and Relational Victimization among Children with Frequent Abdominal Pain: Links to Social Skills, Academic Functioning, and Health Service Use. Journal of Pediatric Psychology, 32(3): 319-329.

GREEFF, M. 2011. Information collection: Interviewing. (In De Vos, A.S., Strydom, H., Fouché, C.B. \& Delport, C.S.L., eds. Research at grass roots: for the social sciences and human service professions. $4^{\text {th }}$ ed. Pretoria: Van Schaik. p. 341-374.)

GREEFF, P. \& GROBLER, A. A. 2008. Bullying during the intermediate school phase. A South African study. Childhood, 15(1): 127-144.

HANSEN, T.B., STEENBERG, L.M., PALIC, S. \& ELKIT, A. 2012. A review of psychological factors related to bullying victimization in schools. Aggression and violent behavior, 17:383-387.

HEPWORTH, D.H., ROONEY, R.H., DEWBERRY-ROONEY, G. \& STROM-GOTTFRIED, K. 2013. Direct social work practice. Theory and skills. 9th ed. Canada: Brooks/ Cole, Cengage Learning.

HJERN, A., GÖSTA, A. \& ÖSTBERG, V. 2008. School stressors, psychological complaints and psychosomatic pain. Acta Paediatrica. 97 (1), p112-117.

HONG, J.S. \& ESPELAGE D.L. 2012. A review of research on bullying and peer victimization in school: a ecological system analysis. Aggression and violent behavior, 17:311-322.

HOWITT, D. 2010. Introduction to qualitative methods in psychology. London: Pearson Education Limited.

JOYCE, P. \& SILLS, C. 2014. Skills in gestalt counselling and psychotherapy. Los Angeles: Sage.

KEYES, C.L.M. 2007. Promoting and protecting mental health as flourishing. A complementary strategy for improving national mental health. American Psychologist, 62(2):95-108.

KNIGHT, C. \& GITTERMAN, A. 2014. Group work with bereaved individuals: the power of mutual aid. Social work, 59(1):5-12.

LAMERS, S. M. A. WESTERHOF, G.J., BOHLMEIJER, E.T., TEN KLOOSTER, P.M. \& KEYES, C.L.M. 2011. Evaluating the psychometric properties of mental health continuum-short form (MHC-SF). Journal of Clinical Psychology, 67(1):99-110.

LOUW, D. \& LOUW, A. 2007. Middle childhood. (In Louw, D. \& Louw, A., eds. Child and adolescent development. Bloemfontein: ABC Printers. p. 214-275.)
MARAIS, P. \& MEIER, C. 2010. Disruptive behavior in the foundation phase of schooling. South African Journal of Education, 30:41-57.

MAX-NEEF, M. 1991. Human scale development. Conception, application and further reflections. New York: The Apex Press.

MISHNA, F. \& SAWYER, J. 2012. The trauma of bullying experiences. (In Ringel, S \& Brandell, J.R. eds. Trauma. Contemporary directions in theory, practice and research. Thousand Oaks: Sage. p 150-165.)

MURRAY-HARVEY,R., SLEE, P.T. \& TAKI, M. 2010. Comparative and cross-cultural research on school bullying. (In Jimerson, S., Swearer, S. M., \& Espelage, D. L., eds. Handbook of bullying in schools. An international perspective. New York: Routledge. p. 35-48.)

NEL, C. 2016. Pyn en vernedering. Meisie uit skool oor boelies. Beeld: 19, 5 Mei.

NESER, J. 2006 Peer victimization in public schools: An exploration of the psychological attributes of a victim. Acta Criminilogica, 19(2):119-141.

OAKLANDER, V. 1988. Windows to our children: A Gestalt approach to children and adolescents. New York: The Centre for Gestalt Development Inc.

OAKLANDER, V. 2007. Hidden treasure: A map to the child's inner self. London: Karnac Books.

OLWEUS, D. 2001. Peer harassment: A critical analysis and some important issues. (In Juvonen, J. \& Graham, S., eds. Peer harassment in school: the plight of the vulnerable and victimized. New York: Routledge. p 7-27).

OLWEUS, D. 2010. Understanding and researching bullying: Some critical issues. (In Jimerson, S., Swearer, S. M., \& Espelage, D. L., eds. Handbook of bullying in schools. An international perspective. New York: Routledge. p. 9-34.)

OLWEUS, D. \& LIMBER, P. 2010. The Olweus Bullying prevention program. Implementation and evaluation over two decades. (In Jimerson, S., Swearer, S. M., \& Espelage, D. L., eds. Handbook of bullying in schools. An international perspective. New York: Routledge. p 377-402.)

OLWEUS, D. \& LIMBER, S.P. 2010. Bullying in school: Evaluation and dissemination of the Olweus Prevention Program. American Journal of Orthopsychiatry, 80(1):124-134.

ORPINAS, P. \& HORNE, A.M. 2010. Creating a positive school climate and develop ing social competence. (In Jimerson, S., Swearer, S. M., \& Espelage, D. L., eds. Handbook of bullying in schools. An international perspective. New York: Routledge. p. 49-60.)

PATTON, D.U., HONG, J.S., WILLIAMS, A.B., \& ALLEN-MEARES, P. .2013. .A review of research relationship between bullying and health-related symptoms. Pediatrics: Official Journal of the American Academy of Pediatrics, 117:1568-1574.

PAVELKA, S. 2013. Practices and policies for implementing restorative justice within schools. The prevention researcher, 20(1):15-17.

PROTOGEROU, C. \& FLISHER, A.J. 2012. Bullying in schools. (In Van Niekerk, A., Suffla, S. \& Seedat, M., eds. Crime, violence, and injury in South Africa: $21^{\text {st }}$ Century solutions for child safety. Tygerberg: MRC-University of South Africa Safety \& Peace Promotion Research Unit. p. 119-133.)

RENSHAW, T.L. \& JIMERSON, S.R. 2012. Enhancing students' attitudes via a brief, universal-level bullying prevention curriculum. School mental health, 4: 115-128.

REYNOLDS, C. \& MORTOLA, P. 2005. Gestalt therapy with children. (In Woldt, A.L. \& Toman, S.M., eds. Gestalt therapy: history, theory, and practice. U.S.A.: Sage. p. 153-178.)

RIGBY, K. 2007. Bullying in schools and what to do about it. Victoria: Acer Press.

RIGBY, K. 2012. Bullying interventions in schools. Six basic approaches. Australia \& New Zealand: Wiley Blackwell A John Wiley \& Sons. 
ROSA, E.M. \& TUDGE, J. 2013. Urie Bronfenbrenner's theory of human development: Its evolution from ecology to bioecology. Journal of Family Theory \& Review, 5:243-258.

ROTHMAN, J. \& THOMAS, E.J. 1994. Intervention research: design and development for human services. New York: Haworth.

ROTHON, C., HEAD, J., KLINEBERG, E. \& STANFIELD, S. 2010. Can social support protect bullied adolescents from adverse outcomes? A prospective study on the effects of bullying on the educational achievement and mental health of adolescents at secondary schools in East London. Journal of Adolescence, 34(3):579-588.

SOLBERG, M.E., OLWEUS, D. \& ENDRESEN, I.M. 2007. Bullies and victims at school: are they the same pupils? British Journal of Educational Psychology, 77: $441-464$

STEINBERG, D.M. 2010. Mutual Aid: A contribution to best-practice Social Work. Social Work with Groups, 33(1):53-68.

STRYDOM, H. 2011. Ethical aspects of research in the social science and human service professions. (In De Vos, A.S., Strydom, H., Fouché, C.B. \& Delport, C.S.L., eds. Research at grass roots: for the social sciences and human service professions. $4^{\text {th }}$ ed. Pretoria: Van Schaik. p. 113-129.)

SULLIVAN, K. 2006. Bullying: How to spot it, how to stop it. A guide for parents and teachers. United Kingdom: Rodale International Ltd.

SULLIVAN, K. 2011. The anti-bullying handbook. $2^{\text {nd }}$ ed. Los Angeles: Sage.

SWART, E. \& BREDENKAMP, J. 2009. Non-physical bullying: Exploring the perspectives of Gr. 5 girls. South African Journal of Education, 29: 405-425.

SWEARER, S.M., ESPELAGE, D.L. \& NAPOLITANO, S.A. 2009. Bullying prevention and intervention. Realistic strategies for schools. New York: Guilford press.

THOMAS, N. 2012. The characteristics that make girls more susceptible to bullying. Master of Education in guidance counseling. UNISA.

TOSELAND, R.W. \& RIVAS, R.F. 2012. An introduction to group work practice. $7^{\text {th }}$ ed. Boston: Pearson Education, Inc.

TTOFI, M. M., TTOFI, D. P. FARRINGTON, A \& BALDRY, C. 2008. Effectiveness of programmes to reduce school bullying. A systematic review. Swedish Council for Crime Prevention, Information and publications.

TUDGE, J.R.H., MOKROVA, I., HATFIELD, B.E. \& KARNIK, R.B. 2009. Uses and misuses of Bronfenbrenner's bioecological theory of human development. Journal of Family Theory and Review, 1:198-210.

THEMLOW, S.W., FONAGY, P. \& SACCO, F.C. 2010. The etiological cast to the role of the bystander in die social architecture of bullying and violence in schools and communities. (In Jimerson, S., Swearer, S. M., \& Espelage, D. L., eds. Handbook of bullying in schools. An international perspective. New York: Routledge. p. 73-86.)

VAILLANCOURT, T., CLINTON, J., MGDOUGALL, P., SCHMIDT,L.A. \& HYMEL, S. 2010. The neurobiology of peer victimization and rejection. (In Jimerson, S., Swearer, S. M., \& Espelage, D. L., eds. Handbook of bullying in schools. An international perspective. New York: Routledge. p. 293-304.)

VAN BOCKERN, S. \& MCDONALD, T. 2012. Creating circle of courage schools. Reclaiming Children and Youth, 20(4):13-17.

VAN DER WALT, J.L. 2012. Another look at education from a Christian stewardship perspective. Koers - Bulletin for Christian Scholarship 77(2), 1-7. http:// dx.doi:10.4102/koers.v78i3.455

WHITTAKER, A. 2012. Research skills for social work. $2^{\text {nd }}$ ed. Los Angeles: Learning Matters Ltd.
YEUNG, R. \& LEADBEATER, B. 2010. Adults make a difference: the protective effects of parent and teacher emotional support on emotional and behavioral problems of peer-victimized adolescents. Journal of Community Psychology, 38 (1): 80-98.

YONTEF, G. \& JACOBS, J. GESTALT THERAPY. 2008. (In Corsini, R. \& Wedding, D., eds. Current Psychotherapies. $8^{\text {th }}$ ed. Belmont: Thomson Brooks/Cole. p. 32.) 